\title{
O PRINCÍPIO DA COOPERAÇÃO NO ÂMBITO DO PROCESSO ADMINISTRATIVO DISCIPLINAR
}

\author{
Sammara Costa Pinheiro Guerra de Araújo ${ }^{83}$ \\ Ana Priscyla Braga Lima ${ }^{84}$
}

Recebido em: 04/05/2019

Aprovado em: 26/08/2019

\begin{abstract}
RESUMO
O presente artigo desenvolve uma investigação acerca da possibilidade ou não da aplicação do princípio da cooperação, também chamado de princípio da colaboração, no âmbito do processo administrativo disciplinar. Para isso, aborda-se a importância do processo administrativo no contexto da Administração Pública contemporânea. Analisa-se, ainda, o espírito do Novo Código de Processo Civil e conceitua um dos seus fundamentos basilares, a cooperação. Verifica-se a aplicabilidade subsidiária e supletiva desse Código a todos os processos administrativos regidos por outras leis, inclusive dentro do processo administrativo disciplinar. Por fim, delimita-se o princípio do devido processo legal e o princípio da cooperação processual no âmbito do processo administrativo, determinando seus efeitos e deveres. Para a realização desse estudo foi feita revisão bibliográfica de obras nacionais e estrangeiras relacionadas ao tema, e empregado o método de abordagem indutivo, calcado nas bases constitucionais e processuais do ordenamento jurídico brasileiro.
\end{abstract}

Palavras-chave: Processo administrativo. Novo código de processo civil. Princípio da cooperação.

\section{INTRODUÇÃO}

O modelo de Administração Pública surgida com o Estado Liberal pode ser caracterizado, genericamente, por agir essencialmente através do ato administrativo. O aparecimento do ato administrativo, em relação ao modelo de Estado que se tinha até então,

\footnotetext{
${ }^{83}$ Mestranda em Direito Constitucional no Programa de Pós-Graduação em Direito-PPGD da Universidade Federal do Rio Grande do Norte-UFRN. Especialista em Direito Constitucional e em Direito Administrativo, ambos pela UFRN. Advogada.

${ }^{84}$ Mestranda em Direito Constitucional no Programa de Pós-Graduação em Direito-PPGD da Universidade Federal do Rio Grande do Norte-UFRN.
} 
trouxe um inegável avanço para a construção de um regime jurídico administrativo que fosse capaz de refrear o exercício do poder, pois sua teoria continha uma ideia essencialmente regulamentadora da atuação estatal, intentando, caso necessário, limitar e proteger os cidadãos de abusos e desvios porventura cometidos pela autoridade administrativa.

Atualmente, procurando não ficar insensível diante dos clamores da sociedade por maior controle, transparência, legitimidade e consensualidade na atuação da Administração Pública, o Direito Administrativo vem passando por profundas mudanças no intuito de responder àquelas expectativas. No cerne dessa transformação, merece papel de destaque o fato do Direito Administrativo, mais do que meramente acolher o fenômeno processual nas atividades administrativas, ter firmemente reconhecido o processo administrativo como um elemento essencial que instrumentaliza e legitima a função administrativa.

Devido essa abertura, ocorreu, nos últimos anos, uma suposta alteração no foco de estudo do Direito Administrativo, deixando mais de lado o olhar centrado no ato administrativo tradicional, passando as atenções, preponderantemente, à figura do processo, mecanismo dinâmico bem sintetiza a ideia de instrumento favorável aos debates e ao intercâmbio dos diversos interesses coletivos.

Deste modo, existe uma tendência contemporânea de deslocar o centro do Direito Administrativo do ato administrativo para o seu modo de formação, ou seja, para o processo administrativo que o antecede.

De fato, colocar o fenômeno processual como núcleo das questões de Direito Público é elevar a dinâmica administração versus administrados, reforçando uma tendência dialética e horizontal, que condiz com a dinâmica de uma administração pública que se encontra a serviço de um Estado Democrático de Direito (art. $1^{\circ}$, caput, $\mathrm{CF} / 88$ ).

É utilizar-se do processo, até mesmo devido ao seu inegável caráter participativo, como uma preciosa alternativa ao restrito ato administrativo, a fim de acolher os anseios sociais existentes, principalmente as que clamam por uma postura mais democrática e transparente da Administração Pública.

Assim, com a passagem de um modelo unilateral para consensual da Administração Pública e de formal para substancial do devido processo legal, impõe-se a necessidade de uma nova configuração na relação jurídico-administrativa de modo a delimitar direitos e deveres que devem ser observados tanto pelos interessados quanto pela autoridade no processo administrativo de forma a alcançar os seus fins.

Neste contexto, o novo Código de Processo Civil traz expressamente a consagração do princípio da cooperação, o qual impõe o dever de colaboração entre a autoridade judicial e as 
partes a fim de que se obtenha, no âmbito do processo civil, um provimento final com uma duração razoável, havendo uma decisão de mérito que possa ser justa e efetiva.

Constitucionalmente, o processo se apresenta como instrumento indispensável à forma do Estado brasileiro. Na verdade, o processo funciona como garantidor da estrutura do Estado Democrático de Direito, e o princípio da cooperação, por seu turno, relaciona-se diretamente com as ideias do devido processo legal (art. 5, LIV, CF/88), contraditório (art. 5 $5^{\circ} \mathrm{LV}$, $\mathrm{CF} / 88$ ), princípio da igualdade (art. $5^{\circ}$, caput, $\mathrm{CF} / 88$ ), além dos direitos fundamentais (Título II, CF/88).

Isso posto, o problema do presente artigo consiste em verificar a possibilidade da aplicação do princípio da cooperação no âmbito do processo administrativo, especialmente no processo administrativo disciplinar, com a finalidade de que o cidadão possa participar do processo de tomada de decisão administrativa.

Sendo o objetivo geral deste artigo verificar possibilidade de aplicação do princípio da cooperação no processo administrativo disciplinar, os objetivos específicos são: i) determinar a importância do processo administrativo no Direito Administrativo contemporâneo; ii) destacar o pluralismo de interesses públicos no processo administrativo; iii) abordar a democratização da Administração Pública e sua importância no ordenamento brasileiro; iv) apresentar o princípio da cooperação no Código de Processo Civil brasileiro e no processo administrativo; v) abordar o devido processo legal, fundamento constitucional da cooperação, no âmbito do processo administrativo; e vi) discutir a aplicação do princípio da cooperação no processo administrativo disciplinar.

Para tanto, empregar-se-á o método de abordagem indutivo, e quanto ao procedimento, a revisão bibliográfica de obras nacionais e estrangeiras concernentes ao tema. A escolha desse método se justifica pela conclusão almejada ser definida por proposições particulares, que conduzem a uma generalização.

As proposições ora utilizadas são disposições constitucionais, processuais civis, administrativas e processuais administrativas do ordenamento jurídico brasileiro e referem-se - precipuamente - a direitos fundamentais, Estado Democrático de Direito, pluralismo de interesses públicos, cooperação processual e devido processo legal.

É com base nessas premissas, que permitem um delineamento das bases constitucionais, processuais e administrativas, além da observação das tendências contemporâneas, que o artigo se dedica a analisar a aplicação do princípio da cooperação no processo administrativo disciplinar com instrumento da participação pelo cidadão no processo de tomada de decisão administrativa. 


\title{
2 A IMPORTÂNCIA DO PROCESSO ADMINISTRATIVO NO DIREITO ADMINISTRATIVO CONTEMPORÂNEO
}

O Direito Administrativo, da forma que atualmente é conhecido, teve sua origem no início do século XIX, com o surgimento do Estado de Direito, na França, onde se buscava uma profunda ruptura entre o Estado e a pessoa do soberano, tendo em vista a extrema necessidade de submeter o poder do monarca à lei, devendo toda atuação administrativa estar sujeita à observância de parâmetros previamente estabelecidos.

Sobre a base ideológica do Direito Administrativo, Celso Antônio Bandeira de Mello (2014, p. 47-48) aduz que:

\begin{abstract}
Portanto, o Direito Administrativo não é um Direito criado para subjugar os interesses ou os direitos dos cidadãos aos do Estado. É, pelo contrário, um Direito que surge exatamente para regular a conduta do Estado e mantê-la afivelada às disposições legais, dentro desse espírito protetor do cidadão contra descomedimentos dos detentores do exercício do Poder estatal. Ele, é, por excelência, o Direito defensivo do cidadão - o que não impede, evidentemente, que componha, como tem que compor, as hipóteses em que interesses individuais hão de fletir aos interesses do todo, exatamente para a realização dos projetos de toda a comunidade, expressados no texto legal. É, pois, sobretudo, um filho legítimo do Estado de Direito, um Direito só concebível a partir do Estado de Direito: o Direito que instrumenta, que arma o administrado, para defender-se contra os perigos do uso desatado do Poder.
\end{abstract}

Foi diante dessa conjuntura, caracterizada principalmente pelo nascimento das primeiras normas disciplinadoras e limitadoras do poder estatal, que emergiu a possibilidade de existência de uma autoridade administrativa distinta da figura do rei, estando aquela sempre vinculada aos impérios da lei.

Surgiu, nessa oportunidade, a concepção de Administração Pública que, à época, era entendida apenas como consequência direta das funções conferidas ao Estado de gerir o bem comum e de promover a ordem social. Percebeu-se, a partir disso, o nascimento de um Estado repaginado, que seria titular de direitos e obrigações e, ainda, responsável por atribuições na seara jurisdicional, legislativa e executiva, tudo com a finalidade de realizar o interesse coletivo e garantir a paz pública.

Destarte, com a criação do Direito Administrativo ficou nitidamente delimitado dois lados. Em um ponta da relação havia a autoridade administrativa que foi instituída pela lei como figura representativa do Estado, a qual possuía competência para impor obrigações aos 
administrados. $\mathrm{Na}$ ponta oposta estavam os cidadãos, titulares de direitos tidos por fundamentais e entendidos como limitadores do poder estatal.

Havia, assim, um relacionamento vertical do Estado para com os administrados, uma percepção hierarquizada do Direito Administrativo marcada por uma superioridade do Poder Público sobre o privado, relação esta que era contrabalanceada pela imposição de regras e deveres ao Estado e pela concessão de liberdade aos administrados.

A necessidade de harmonização dessa relação gerada a partir do reconhecimento tanto dos direitos dos particulares quanto da autoridade da Administração Pública cooperou demasiadamente para a elevação do Direito Administrativo a ramo do direito autônomo.

O contexto era, então, bastante propício para que houvesse uma notada separação entre as esferas pública e privada, o que se justificava principalmente pela noção acabada e delimitada que havia, na época, sobre a ideia de interesse público e privado.

O conceito que se detinha acerca de interesse público se restringia ao simples sentido de mero interesse da coletividade, o qual viria expresso na lei ou legalmente delegado à Administração Pública. Já o interesse privado correspondia diretamente ao interesse individual, sendo entendido como o empenho na concretização das vontades dos particulares, que, até então, eram vistas como desassociadas de qualquer conteúdo coletivo.

Entretanto, nos dias de hoje percebe-se que a concepção de interesse público tem passado por uma intensa transformação, pois, diante de muitos grupos e interesses existentes na sociedade atual, é importantíssimo harmonizar esse acúmulo de interesses públicos coexistentes, deliberando-se, sempre que imprescindível, pela prevalência de um sobre outro.

Odete Medauar (2003, p. 129-131), discorrendo acerca das transformações ocorridas na Administração Pública durante as duas últimas décadas, expõe que foi igualmente verificado, nesse período, ao lado de uma crescente e constante aproximação do poder público com a comunidade, uma série de outras tendências nas ações da Administração Pública.

Como exemplo, cita o predomínio da transparência em detrimento do segredo, da transferência de atividades para agentes particulares, da utilização de institutos de direito privado, da diminuição do exercício do denominado poder de império, do aumento do controle pelo resultado, do uso de convenções e contratos para a solução de problemas, da desregulamentação e do desenvolvimento das atividades de forma policêntrica (MEDAUAR, 2003, p. 131).

Diante das profundas modificações na estrutura e no comportamento da Administração Pública, é incontestável que, da mesma maneira, o Direito Administrativo venha a suportar, no presente século, atuais e estimulantes desafios. 
Para que ocorra o enfrentamento desses desafios, é necessário a ruptura de muitos de seus tradicionais paradigmas, o que, por si só, já caracteriza uma de suas atuais direções, se adequando aos anseios da sociedade moderna.

Destarte, registrando vagamente as transformações ocorridas no posicionamento da Administração Pública e nos paradigmas do Direito Administrativo, este capítulo demonstrará o relevante papel que, nos dias atuais, o processo administrativo desempenha nas atividades da Administração Pública, tendo como finalidade evidenciar a intensa relação de reciprocidade que há entre o processo administrativo e essa nova tendência que tem adquirido o Direito Administrativo contemporâneo.

\subsection{O processo administrativo e o pluralismo de interesses públicos}

A noção de interesse público, desde o final do século $\mathrm{XX}$, vem passando por uma intensa releitura. Até meados do século anterior as ideias de interesse público e do interesse da própria Administração Pública se misturavam. Hoje, diante dos diversos grupos sociais que cooperam na identificação de interesses públicos reconhecidamente plurais e com a suavização na superioridade da Administração, essa confusão de conceitos não mais se admite, assim como não mais se emprega um conceito singular de interesse público.

$\mathrm{Na}$ atualidade, além de simplesmente identificá-lo e distingui-lo do interesse privado, busca-se, de fato, conciliar os plurais e reconhecidos interesses públicos coexistentes, deliberando-se, no caso concreto, pela prevalência de um sobre outro.

Por conseguinte, há de se entender o sentido plural do interesse público como um conjunto de interesses públicos que serão apontados, ponderados e equilibrados diante das circunstâncias concretas. Não há possibilidade de se pensar na prevalência ou existência de apenas um interesse público supremo em relação aos demais, que tenha sido identificado unilateralmente pela Administração Pública.

Mariana de Siqueira (2016, p. 152-153), ao abordar o pluralismo de interesses públicos, assim assevera:

Se o Estado é reflexo da sociedade, e se a sociedade atual traz com ela a marca da diversidade, o Estado contemporâneo insere dentro de si essa diversidade. A Administração Pública, por sua vez, pertencente a esse Estado, também vive os reflexos do fenômeno da pluralidade. O interesse público, fruto dos anseios sociais, fim e fundamento da atuação da Administração, por óbvio que reproduz essa multiplicidade de interesses que é marca da coletividade. Não há, assim, "o interesse público", mas sim vários interesses públicos passíveis de tutela jurídica por possuírem compatibilidade formal e material com a Constituição de 1988. 
Humberto Ávila (2007, p. 207-211) aponta a existência de muitos interesses qualificáveis como públicos e que podem, também, em certos casos, colidir entre si, a exigir ponderação, bem como a presença de elementos privados contidos na definição de interesse público. Mesmo os interesses de particulares não absorvidos pelo interesse público devem ser alvo de ponderação no caso concreto.

Nesse cenário, se sobressaem conceitos como o de administração cooperativa, baseada em uma coordenação de interesses, e se discute o propósito de se promover a proteção de interesses no seio de uma sociedade multicultural, conduzindo, assim, novas atribuições à Administração Pública.

Isso porque, anteriormente, era a Administração a única competente pela fixação do que seria matéria afeta ao interesse público e, atualmente, ela apenas adota a posição que analisar mais adequada ao caso, não se manifestando senão a partir de seleção criteriosa e motivada de um ou de alguns dos interesses públicos subjacentes.

Sobre essa questão, Gustavo Binenbojm (2008, p. 25) aduz que:

A definição do que é o interesse público, e de sua propalada supremacia sobre os interesses particulares, deixa de estar ao inteiro arbítrio do administrador, passando a depender de juízos de ponderação proporcional entre os direitos fundamentais e outros valores e interesses metaindividuais constitucionalmente consagrados.

Nesse ponto é que se compreende a enorme utilidade de que se reveste o processo administrativo, pois é ele o instrumento adequado para a identificação de quais interesses públicos prevalecerão em dada situação concreta, tornando-se uma fundamental ferramenta de que dispõe a Administração Pública para realizar, com segurança, a ponderação desses interesses públicos existentes.

A relevância dessa processualidade está, então, ligada ao reconhecimento da hodierna ideia que se tem acerca da 'multiplicidade de interesses públicos', expressão típica dentro do Direito Administrativo contemporâneo.

\subsection{O processo administrativo e o Estado de Direito}

Não deve mais prevalecer a caracterização do Estado de Direito, tão somente, como aquele onde seja observada a submissão do poder público ao ordenamento jurídico vigente, pois, atualmente, suas premissas são dinâmicas e, cada vez mais, variadas são suas facetas.

A razão disso é que as relações sociais, no geral, evoluíram e, consequentemente, novos valores foram selecionados com o intuito de guiar e direcionar a ação estatal. Com a 
dinâmica das relações sociais, o Estado de Direito foi levado a se vincular à concretização de deveres jurídicos positivos, impostos por seu próprio ordenamento.

A atuação estatal não poderia se limitar apenas em abster-se de praticar condutas legalmente vedadas. Deveria a Administração Pública abranger, no rol de suas atribuições, a execução eficaz de deveres estabelecidos na lei, conforme aconteceu na passagem do Estado Liberal para o Estado Social, a qual exigiu uma postura positiva do poder público.

A deficiência do modelo do Estado Liberal culminou com o advento do Estado Social, tendo como marcos jurídicos a Constituição Mexicana, de 1917, e a de Weimar, em 1919, em resposta às dificuldades sociais da época, sobrevindo o Estado a exercer um papel intervencionista, tanto na economia quanto nas relações privadas, devendo Estado garantir os direitos sociais mínimos.

Nessa perspectiva, surge o questionamento de como ocorreria a implementação desses deveres positivos através do Estado. A resposta constitucional a esta provocação é o uso de processos administrativos.

A processualização da atividade estatal é necessária para que haja a ponderação de interesses públicos contrapostos e para que a Administração Pública intensifique seu dever de concretização dos direitos fundamentais.

A processualização é, então, inerente ao exercício do poder estatal, como bem demonstra Carlos Ari Sundfeld (1987, p. 67) quando afirma que o processo "é o modo normal de agir do estado, sendo consequência direta da ideia de função".

Nesse sentido, o processo administrativo tem se mostrado um verdadeiro direito subjetivo público dos cidadãos. No Brasil, ele está expressamente contemplado no art. $5^{\circ}$, inciso LV, da Constituição Federal. Esse é o entendimento adotado por Robert Alexy (2011, p. 477 e ss), que assegura ser o direito à processualização, quando tomado pelo ângulo do indivíduo, um autêntico direito fundamental com caráter positivo.

O agir positivo do poder público através do processo, atendendo diretamente a ordem constitucional, garante, consequentemente, a efetividade do exercício de direitos fundamentais pelos particulares.

Odete Medauar (2008, p. 86-87) sinaliza uma aproximação entre o processo administrativo e o Estado de Direito. A imposição de limites ao poder público através de um ordenamento jurídico, fundamento estruturante que norteia o Estado de Direito, está em plena concordância com o regime jurídico próprio do processo administrativo, pois, analisando as duas visões, ambas procuram constituir parâmetros e atribuir previsibilidade à atuação da atividade administrativa. 
Ademais, o princípio da igualdade, base do Estado de Direito, é imperativo constante no processo administrativo. Isso porque os seus participantes dispõem de idênticas oportunidades de argumentar e provar.

Quanto à garantia dos direitos fundamentais, o processo administrativo busca amenizar supostos arbítrios e desvios de finalidade que porventura venham ocorrer, delimitando a atuação administrativa.

Odete Medauar (2008, p. 86-87) assevera que "o contraditório e a ampla defesa, que lhe são inerentes, fornecem condições para pleitear o reconhecimento de direitos na esfera administrativa", visualizando o processo como mecanismo de tutela de direitos na administração pública.

Portanto, ao fazer com que a atividade administrativa corra sobre os contornos da lei, o processo acaba por se transformar num instrumento de proteção dos direitos fundamentais, conforme enfatiza Egon Moreira (2010, p. 69):

\footnotetext{
A principal preocupação daquele que estuda direito administrativo não hão de ser as 'prerrogativas da Administração', mas os 'direitos do administrado'. O processo administrativo significa meio ativo de exercício e garantia dos direitos dos particulares, que têm condições de participar e controlar a sequência predefinida de atos anteriores ao provimento final.
}

Odete Medauar (2008, p. 24) entende o processo administrativo como uma garantia de limitação do poder, de cumprimento das funções estatais e de respeito aos direitos fundamentais.

Em virtude desse evidente cunho protetor de direitos fundamentais cedido ao processo administrativo, assim como no processo judicial, aquele não pode ser encarado como um mero formalismo ou passagem para a confirmação de uma vontade estatal, mas sim como uma garantia da ampla participação do cidadão na formação da decisão final, como uma garantia estruturante do Estado Democrático de Direito.

A Constituição Federal de 1988 remodelou a atividade administrativa ao adotar o Estado Democrático de Direito. A participação plena e igualitária do cidadão na concretização dos interesses do Estado revela um Direito Administrativo constitucionalizado que não admite uma administração focada apenas na defesa do Estado, mas sim na submissão à processualidade constitucional administrativa como meio garantidor da concretização dos direitos fundamentais, a exemplo do devido processo legal que será aqui abordado. 
A democracia ainda é, atualmente, um dos valores mais relevantes e perseguidos em grande parte das civilizações ocidentais. Sua essencialidade é tamanha que Paulo Bonavides (2003, p. 571) fala no direito do cidadão à democracia, o inserindo no rol dos direitos fundamentais de quarta geração que, nas palavras do autor, têm por característica o fato de emergirem com caráter universal e em meio ao cenário de globalização política.

A conceituação de democracia deve ser analisada diante do processo histórico e das várias fases evolutivas vivenciadas pela sociedade, possuindo tal definição um caráter dinâmico resultante das transformações ocorridas na sociedade a cada época e contexto político estudado. Não é de causar estranheza, contudo, que tenha sido assim. José Afonso da Silva (2008, p. 131) defende essa dinamicidade como algo que lhe seja inerente:

\footnotetext{
Não percebem que ela é um processo, e um processo dialético que vai rompendo os contrários, as antíteses, para, a cada etapa da evolução, incorporar conteúdo novo, enriquecido de novos valores. Como tal, ela nunca se realiza inteiramente, pois, como qualquer vetor que aponta a valores, a cada nova conquista feita, abrem-se outras perspectivas, descortinam-se novos horizontes ao aperfeiçoamento humano, a serem atingidos.
}

Apesar das diferentes acepções, é consenso que o núcleo essencial do conceito de democracia é sempre estruturado pelo sentido advindo da própria etimologia da palavra, em que o poder de tomar decisões políticas está com o povo. É assim, inclusive, a atual percepção da democracia, consagrada nos modernos ordenamentos constitucionais, que têm origem no povo e de onde se origina o protótipo constitucional dos Estados Democráticos.

O caráter democrático deve necessariamente abarcar a participação efetiva e operante da população na coisa pública, não ficando consinto, todavia, à simples formação das instituições representativas. A democracia deve ser entendida na plenitude de seu conteúdo e na total extensão dos valores cujo alcance se propõe a instrumentalizar, não se aceitando que ela fique restringida somente a prerrogativa de escolha de seus governantes.

Pautado nesse pensamento, se iniciou, na metade do século XX, uma forte inquietação na busca de se implementar a participação efetiva do povo no exercício do poder, verdadeira excelência democrática. Assim, começou a ganhar força a denominada democracia administrativa, que tem origens fincadas na garantia de se permitir ao cidadão sua efetiva participação na construção do conteúdo das decisões governamentais que possam afetá-lo.

Ao abordar a democratização no âmbito da Administração Pública, José Joaquim Gomes Canotilho (1999, p. 25) compreende que ela manifesta-se na substituição das estruturas hierárquico-autoritárias por formas de deliberação colegiada, como a introdução do voto na seleção das pessoas a quem foram confiados cargos de direção individual, na 
transparência ou publicidade do processo administrativo e na gestão participada, que consiste na participação dos cidadãos por meio de organizações populares de base e de outras formas de representação na gestão da Administração Pública.

Consolidou-se, nas últimas décadas, o entendimento de que a democracia plena não existe sem que o povo possa intervir ou colaborar, de forma concreta, no processo de formação das decisões estatais. Um padrão democrático de atuação, no qual devem sempre prevalecer, na construção conjunta das decisões, o consenso e o diálogo com os administrados, que já não mais são tratados como súditos, mas sim como verdadeiros companheiros do poder público na tarefa de ponderação dos interesses.

A participação administrativa, segundo Odete Medauar (2003, p. 230) refere-se:

(...) à identificação do interesse público de modo compartilhado com a população, ao decréscimo da discricionariedade, atenuação da unilateralidade na formação dos atos administrativos e às práticas contratuais baseadas no consenso, negociação e conciliação de interesses.

Assim, fica fácil assimilar a importância categórica que o processo administrativo desempenha nessa nova relação entre a Administração Pública e os particulares, pois não se conhece, ainda, outro instrumento que, da mesma forma que o processo, aglomere tantas qualidades favoráveis à efetiva inclusão do cidadão, na qualidade de partícipe, no conjunto de atividades administrativas executadas pelo Estado.

O processo administrativo constitui, assim, o modus operandi para o Estado efetivar o interesse público, na qualidade de representante e não de titular. É exatamente na face instrumental do processo administrativo que a democracia descobre um ambiente apto à sua forma plena de realização.

A importância de processos administrativos transparentes, acessíveis aos cidadãos e que admitam que o particular acompanhe todo o procedimento de tomada de decisão tendem a diminuir a insegurança jurídica e os riscos de violação aos direitos e garantias individuais dos cidadãos. A consequência disso é uma decisão administrativa mais democrática e justa, legitimada pelo próprio cidadão.

3 O NOVO CÓDIGO de PROCESSO CIVIL E A COOPERAÇÃO NO PROCESSO ADMINISTRATIVO BRASILEIRO 
Com a declarada finalidade de se buscar uma maior agilidade da justiça, buscando uma maior celeridade no processo e a possibilidade de desafogar o Judiciário, o Código de Processo Civil brasileiro de 1973 foi substituído por um novo diploma legislativo, promulgado em 16 de março de 2015.

O novo Código traz todas as suas premissas fincadas na Constituição de 1988. Humberto Theodoro Júnior (2015, p. 70) destaca que a referida lei processual almejou a constitucionalização do processo e aplicação dos princípios constitucionais:

\begin{abstract}
Na Parte Geral, o Novo Código dispensou grande atenção à constitucionalização do processo, dedicando seus 12 artigos iniciais para definir aquilo que denominou de Normas Fundamentais do Processo Civil, entre as quais merecem especial destaque os princípios do contraditório sem surpresas; da cooperação entre partes e juiz na atividade de formulação do provimento jurisdicional; da sujeição de todos os participantes do processo ao comportamento de acordo com a boa-fé; da duração razoável do processo; da dignidade da pessoa humana; da eficiência da prestação a cargo do Poder Judiciário; da submissão do próprio juiz ao contraditório; da fundamentação adequada das decisões judiciais; da vedação de privilégios da ordem de julgamento das causas.
\end{abstract}

A nova codificação processual civil almeja um progresso na forma de entender o instrumento que viabiliza a prestação jurisdicional. A inserção de dispositivo que exige a cooperação dos atores do processo, conforme expresso no seu art. $6^{\circ}$, é bastante inovadora e requer um estudo mais aprofundado sobre suas implicações.

\title{
3.1 A cooperação processual
}

Na busca de uma nova perspectiva que alivie o sistema judiciário brasileiro, a nova lei processual trouxe como uma de suas bases o princípio da cooperação. Classicamente, processualistas como Fredie Didier Júnior (2017, p. 136-139), ao se referirem sobre a organização do processo a partir de uma distribuição de funções entre os sujeitos processuais, identificam o modelo adversarial, também chamado de dispositivo, e o modelo inquisitorial.

Todavia, antes mesmo da promulgação do Novo Código de Processo Civil, os processualistas já passaram a discorrer também sobre o recente modelo cooperativo.

O processo dispositivo é característico do Estado Liberal, no qual as partes eram competentes para dirigir o processo, ao passo que o juiz, intitulado boca da lei, possuía uma posição de neutralidade e passividade, responsável apenas por proferir a decisão, não tendo liberdade para interpretar as leis, mas apenas aplicá-las. Nesse sentido, Carlos Alberto (2010, p. 66-67) asseverou que "qualquer espécie de poder judicial era ignorado ou pelo menos muito atenuado: o juiz deveria permanecer totalmente estranho à direção do processo". 
Já o modelo inquisitivo revela-se oposto, pois é o magistrado quem tem a administração do processo e não mais as partes. Neste modelo é conferido ao juiz não apenas o domínio na condução do processo, mas também o poder de perquirir as provas indispensáveis para comprovar os fatos, mesmo sem requerimento ou cooperação das partes. O cerne deste modelo está, portanto, na livre inquirição dos fatos pelo julgador.

Em ambos os modelos coexistem os princípios inquisitivo e dispositivo, o que os diferencia é uma maior atribuição pelo legislador de poderes ao magistrado ou às partes.

No Brasil, apesar de haver traços dos dois modelos, buscando a ideia de efetividade como caminho e objetivo da processualística moderna, surge a necessidade de um novo modelo que inove na distribuição das funções dos sujeitos processuais e que ampare o direito das partes de participarem concretamente na formação da decisão judicial. A partir do equilíbrio dos modelos inquisitivo e dispositivo e da necessidade de evoluir o modelo processual decorreu a ideia do processo cooperativo.

Lúcio Grassi de Gouveia (2000, p. 248) assegura que o princípio da cooperação tem sido adotado pelos ordenamentos jurídicos de diversos países do continente europeu, tendo a doutrina atribuído a origem do instituto ao direito alemão.

O novo Código de Processo Civil brasileiro traz um título e um capítulo dedicados às normas fundamentais do processo civil, dentre as quais se destaca o art. $6^{\circ}$, o qual exige expressamente que todos os sujeitos do processo cooperem entre si para que se obtenha a solução do processo com efetividade e em tempo razoável.

No entender de Marinoni e Daniel Mitidiero (2016, p. 187) a colaboração é:

[...] um modelo que visa a organizar o papel das partes e do juiz na conformação do processo, estruturando-o como uma verdadeira comunidade de trabalho (Arbeitsgemeinschaft), em que se privilegia o trabalho processual em conjunto do juiz e das partes (prozessualen Zusammenarbeit). Em outras palavras: visa dar feição ao formalismo do processo, dividindo de forma equilibrada o trabalho entre todos os seus participantes.

Por conseguinte, cooperação, ou colaboração, significa a participação e o diálogo entre os sujeitos processuais na tomada de decisões, sendo a própria dialética processual. Em razão disso, o juiz deixa de ser o autor único e solitário de suas decisões. As decisões judiciais passam a ser fruto de uma atividade conjunta. Contribuindo com esse entendimento, Leonardo Carneiro da Cunha (2013) assevera que "em razão do contraditório, a atividade jurisdicional deve pautar-se num esquema dialógico, de modo a exigir que o juiz exerça a jurisdição com o auxílio das partes, proferindo decisão legítima, aprimorada e justa". 
No modelo processual cooperativo o princípio da cooperação é o norteador do processo, sendo este embasado diretamente pelos princípios do devido processo legal, da boafé processual e do contraditório, todos princípios garantidos pela Constituição. Pode-se afirmar que este é um modelo mais democrático. De acordo com Mitidiero (2011, p. 17) é um processo "pautado pelo diálogo judiciário, pela colaboração e pela lealdade entre as pessoas".

Dierle Nunes (2008, p. 215) defende esse novo modelo onde o processo é conduzido por uma comunidade de trabalho, sem protagonismo, alegando ser democrático e compatível com a Constituição e sugerindo que esse é um modelo constitucional de processo.

Nesse modelo o magistrado atua como garantidor dos direitos fundamentais, possibilitando o debate, a discussão e a participação cooperativa das partes no processo, com objetivo de que seus argumentos sejam considerados na formação das decisões.

Procura-se, assim, um equilíbrio na participação processual, estruturado na divisão do trabalho entre o órgão jurisdicional e as partes, onde se diminui os protagonistas e há uma divisão mais paritária na direção e no diálogo processual.

Por outro lado, o magistrado não pode, baseado na noção de colaboração, ser um mero conselheiro ou conciliador de conflitos, motivando suas decisões na cooperação realizada pelas partes. O juiz deve conduzir o processo de maneira dialogal, mas no momento de tomada da decisão deve ser assimétrico.

O julgamento no processo cooperativo acontece como consequência da atividade processual em cooperação, ou seja, advém de discussões realizadas durante o processo, por meio de uma cognição compartilhada. Entretanto, na ocasião de pronunciar a sentença, o poder decisório compete ao magistrado, tratando-se de atribuição exclusiva do órgão jurisdicional (DIDIER JÚNIOR, 2017, p. 142).

Para que a cooperação aconteça é necessária a mudança de postura dos operadores do direito e das partes no sentido de afastar a mentalidade individualizada e se aproximar de uma prestação jurisdicional baseada na boa-fé, no devido processo legal e no contraditório, fundamentos constitucionais da cooperação processual.

\subsection{O Devido Processo Legal no processo administrativo}

Foi somente com a Constituição Federal de 1988 que o devido processo legal foi laureado, tendo o art. $5^{\circ}$ dessa Lei Maior o incluído entre os direitos e garantias individuais, nos termos do seu inciso LVI, no qual resta disciplinado que "ninguém será privado da sua liberdade ou de seus bens sem o devido processo legal". 
Apesar de frequentemente ser compreendido como umas garantias do processo judicial, principalmente do processo penal, o devido processo legal deve ser analisado como uma garantia limitadora do exercício de quaisquer dos poderes na concretização de qualquer processo público, possuindo integral e imprescindível aplicabilidade no âmbito do processo administrativo (GRINOVER, 2010, p. 357). Assim, não trata-se de um princípio específico de um ou outro tipo de processo, sendo, de fato, garantia de todos e do próprio ordenamento.

Mariana Siqueira (2016, p. 244) assevera que o processo administrativo, como forma de legitimação do agir da Administração, “deve desenvolver-se com respeito ao devido processo legal, a partir de caminhos previamente estabelecidos, minimamente previsíveis, com respeito às formalidades necessárias, buscando evitar arbitrariedades”.

Dessa maneira, Ada Pelegrini Grinover (2010, p. 357) fala na existência de um devido processo legal administrativo, o qual deve estar presente no cerne da relação jurídicoprocessual que é estabelecida entre a Administração Pública e o administrado, tanto no aspecto procedimental, respeitando todo o procedimento legal, a exemplo do rito, competência e decisão, como no aspecto substancial ou material, em relação ao conteúdo a ser considerado na decisão administrativa.

Portanto, na esfera administrativa, o reconhecimento do due process of law no aspecto procedimental e substancial acarreta que a atuação administrativa sobrevenha através da instauração de um procedimento formal, o qual não pode estar sujeito à discricionariedade e abuso de poder da autoridade administrativa, devendo ser capaz de garantir a participação dos cidadãos, trazendo legitimidade, previsibilidade e a racionalidade às decisões proferidas.

Sob o aspecto procedimental do devido processo legal, que possui sua acepção inicial no respeito ao contraditório e ampla defesa, é essencial reconhecer a sucessão de atos administrativos previstos em Lei, os quais buscam minimizar a restrição indevida à esfera de direitos do particular. Isso significa que a não obediência às formalidades processuais administrativas afronta a cláusula do devido processo legal procedimental, sem falar na ofensa à Lei 9.784, de 29 de janeiro de 1999, que regulamenta o processo administrativo federal.

Quanto ao contraditório, este trata da faculdade do particular de revelar o seu próprio ponto de vista ou trazer seus próprios argumentos em resposta aos fatos, documentos ou pontos de vista apresentados pela Administração Pública ou por outro sujeito processual. Abarca os direitos à comunicação dos atos, a produção de provas, apresentação de alegações finais e a interposição de recursos, dentre outros, no âmbito do processo administrativo contencioso, onde exista litígio ou nos casos em que puder aplicar sanções ao administrado. 
Odete Medauar (2008, p. 102) aponta que o Princípio do Contraditório tem finalidade instrutória e garantista:

[...] visa à tutela das posições jurídicas dos destinatários do ato final; tal proteção se efetua no seu aspecto genérico, pois enseja a colaboração do sujeito na fixação do conteúdo do ato; e se efetua no seu aspecto reativo, por oferecer possibilidade concreta de melhor combater o ato final, se lesivo a direitos. (...) a instrução contraditória protege o indivíduo contra o poder coercitivo da administração.

Vladimir França (2001, p. 221) entende que a função do contraditório é conceder maior segurança à administração, democratizando o exercício da atividade administrativa e garantindo o respeito à cidadania e à dignidade da pessoa humana.

Ainda no aspecto procedimental, Celso Ribeiro Bastos e Ives Martins (2004, p. 287) asseveram que o direito à ampla defesa deverá ser amplo, acarretando maiores condições para que os particulares possam trazer para o processo os elementos lícitos propensos a elucidar a verdade e contribuir no processo de construção da decisão. Alguns exemplos de proteção à ampla defesa estão consignados no artigo $3^{\circ}$, incisos I, II, III e IV da lei que regula o processo administrativo federal, os quais permitem que o cidadão exerça plenamente os seus direitos no processo administrativo.

De acordo com Sérgio Ferraz e Adilson Abreu Dallari (2007, p. 91), o direito à ampla defesa impõe à autoridade o dever de fiel observância das normas processuais e de todos os princípios jurídicos incidentes sobre o processo.

Em relação ao conteúdo substancial do devido processo legal, este abrange os postulados da razoabilidade e proporcionalidade na deliberação pela autoridade administrativa.

O postulado da razoabilidade pode ser entendido como imposição de presunção de normalidade, por meio da harmonização das regras e princípios, com a intenção de emergir uma congruência entre a situação fática e solução administrativa. Assim, impõe deveres à Administração Pública com o objetivo de que a ação administrativa ocorra dentro dos padrões normais da aceitabilidade ética.

Já o núcleo fundamental da proporcionalidade exige uma ação equilibrada por parte da administração dentro do processo, entre ato processual exercitado e efeito produzido. A proporcionalidade atinge o dever de selecionar a medida restritiva menos onerosa dentre as possíveis e que ocasione mais benefícios ao sujeito processual, resultando no fim almejado.

Relevante destacar, ainda, que o princípio do devido processo administrativo também se manifesta, perante o atual Estado Democrático de Direito, na necessidade de efetiva 
participação do administrado nas tomadas de decisão da Administração Pública, especialmente nas situações que resulte em restrição aos direitos do cidadão.

Portanto, o direito ao devido processo legal compreende a igualdade de recursos das partes envolvidas, para que exista equilíbrio entre os sujeitos processuais. A igualdade não apenas formal, mas também material, é o desígnio maior dessa garantia, que se utiliza do princípio da cooperação, objeto do presente artigo, para reger o processo administrativo, como forma de conferir, mediante a participação dos administrados, maior legitimidade e eficiência a decisão administrativa e se adequar ao modelo de Administração Pública Contemporânea.

\subsection{A Cooperação no processo administrativo disciplinar}

O princípio da cooperação, ao ser consagrado no artigo $6^{\circ}$ do novo código, conferiu à autoridade e às partes em um processo o dever de cooperação entre si para que se possa obter no provimento final, dentro da duração razoável do processo, uma decisão de mérito que possa ser justa e efetiva.

Para se alcançar uma decisão justa é necessário que todo o processo seja justo, compreendendo a igualdade de recursos das partes envolvidas, para que exista equilíbrio entre os sujeitos processuais. A igualdade não apenas formal, mas material, traduz condição básica para um devido processo legal. Se as armas ou instrumentos são flagrantemente desiguais, a decisão justa não passará de expectativa sem qualquer alcance no mundo real.

No âmbito do processo administrativo disciplinar, analisando a relação entre Poder Público e o cidadão, o assunto ganha maior destaque na medida em que nesse processo existe uma peculiaridade: a relação não é triangular, pois a Administração Pública assume dupla função. Ela acumula a função de parte interessada na demanda e de julgadora, dificultando o equilíbrio da decisão, ainda que estas decisões não possuam um caráter definitivo.

Dessa forma, se no processo administrativo disciplinar já existe uma diferenciação entre o servidor e a Administração Pública devido a dupla função por esta assumida, não estaria compatível com a Constituição a ideia de que a Administração, na posição de parte interessada, permanecesse em posição privilegiada, ostentando recursos e forças não extensíveis ao servidor.

Nesse contexto, como forma de tentar resgatar o equilíbrio no processo administrativo disciplinar, o princípio da cooperação almeja o protagonismo de todos os sujeitos processuais de forma isonômica e pondera o formalismo, princípio inerente ao processo administrativo disciplinar. 
O princípio do formalismo moderado prevê que o processo siga de forma mais simplificada com o objetivo de produzir uma decisão célere sem, entretanto, deixar de observar as garantias processuais do contraditório, da ampla defesa e do devido processo legal. Contribuindo com essa finalidade, o princípio da cooperação vem trazer uma relação mais equânime e uma maior discussão e participação das partes no decorrer do processo, o que, por si só, já torna a marcha processual mais célere, sem ferir as garantias constitucionais.

De acordo com Lênio Streck, Lúcio Delfino e Ziel Ferreira Lopes (2014, p. 2), em um sistema processual cooperativo, no qual o resultado do processo é produto do diálogo simétrico e horizontal entre as partes, não há lugar para protagonistas, a decisão é resultado das partes durante todo o iter procedimental, demonstrando, especialmente, que o processo tem uma estrutura policêntrica onde se constrói a legitimidade decisória.

Por efeito, todos os atores do processo, a partir de diferentes perspectivas e em conformidade com o papel desempenhado ao longo do processo contribuem para a formação de um discurso que servirá de fundamento para uma decisão correta, sem atuar com subordinação, mas de modo interdependente, permitindo a construção de decisões qualitativamente melhores, normativamente mais corretas (THEODORO JUNIOR; NUNES; BAHIA; PEDRON, 2015, p. 114).

Participando ativamente no processo administrativo disciplinar, as partes acabam por legitimar a decisão final, além de melhor compreenderem os elementos que compõe essa decisão. A celeridade é resultante justamente da discussão dialógica, uma vez que ao cooperar, cada uma das partes auxilia na coleta de informações necessárias para que a administração profira uma decisão sobre o litígio.

A cooperação processual ativa é, exatamente, aquela que envolve a participação direta do administrado, à exemplo dos documentos enviados pela parte ou informações prestadas após serem requisitadas pela autoridade administrativa. Entretanto, a cooperação passiva é compreendida como a não criação de obstáculos ou barreiras à investigação e a lealdade e a boa-fé processual.

Adentrando no princípio do interesse público aplicado ao processo administrativo disciplinar, percebe-se que a cooperação satisfaz ao interesse da coletividade, posto que, na medida em que traz um viés mais democrático ao processo, estar-se-á atingindo o interesse de toda sociedade, mesmo que aparentemente individualizada nas partes, pois fomenta-se a garantia dos direitos constitucionais. Por outro lado, e não menos importante, há ainda o interesse no andamento e resultado do processo, tolhendo incisivamente os abusos de poder, 
atos irregulares e ilegais, em virtude de esclarecer aos participantes do processo, através do diálogo, a agirem de forma mais efetiva e eficiente.

$\mathrm{Na}$ relação processual administrativa decorrem, em virtude do princípio da cooperação, deveres tanto para o administrado como para a Administração Pública. No que se alude aos deveres dos administrados, cita-se, à título de exemplo, o dever de veracidade, o dever de lealdade, a proibição de temeridade e o dever de informação e colaboração. Trata-se de cooperação processual do cidadão em benefício da administração, os quais estão expressamente disciplinados no $\operatorname{artigo} 4^{\circ}$ da Lei $n^{\circ} 9.784 / 99$, lei do processo administrativo no âmbito da Administração Pública Federal, que é utilizada subsidiariamente no processo administrativo disciplinar.

Daí a exigência legal que as partes se conduzam no processo segundo os preceitos da cooperação. Para o administrado o dever de veracidade significa que o servidor processado não poderá utilizar de expediente falacioso no qual se falta com a verdade produzindo argumentos de impostura e mendacidade. A cooperação expurga desde logo, comportamentos de intencional falsidade, dissimulação ou perfídia no processo administrativo disciplinar.

Ressalta-se que o órgão processante também é composto por servidores públicos que representam o Estado e, dessa maneira, está revestido pela responsabilidade civil, penal e administrativa. Assim, a cooperação exclui informações falsas dos membros da comissão processante do PAD enquanto Estado, os quais respondem por seus atos praticados na qualidade de agentes. Daí sua obrigação com a exposição da verdade.

Assim como o cidadão tem o dever de cooperar com a Administração Pública no exercício de suas funções, às autoridades, aos órgãos e às entidades públicas compete a tarefa de auxiliar os cidadãos no exercício de seus direitos e no cumprimento de seus deveres expressamente consagrada na lei que regula o processo administrativo no âmbito da Administração Pública Federal. São direitos dos administrados, previstos no artigo $3^{\circ}$ da Lei $\mathrm{n}^{\circ}$ 9.784/99, o direito de ser respeitado, o direito à informação, o direito à alegações e comprovações e o direito a representação.

Corroborando com a existência de deveres de cooperação atribuídos à autoridade administrativa, assim expõe Thiago Marrara (2016):

A cooperação para o exercício dos direitos gera para a autoridade pública o dever de informar os cidadãos sobre os requisitos, condições e procedimentos para o devido gozo de direitos individuais, coletivos e difusos mesmo quando tal autoridade não esteja expressamente obrigada a se manifestar. O Estado, constatando as dificuldades do indivíduo para concretizar sua cidadania, deve agir de ofício, oferecendo-lhe as informações e, quando cabível, as condições materiais para que possa gozar de seus direitos legalmente garantidos. O fundamento para tanto é 
óbvio: se o Estado existe pelo povo e para o povo, não podem as autoridades públicas quedar inertes frente às dificuldades de um cidadão para compreender a ordem jurídica e, com base em seus mandamentos, exercer seus direitos.

Por outro lado, a cooperação para a execução de deveres pelo cidadão também é imprescindível. A violação das normas nem sempre é intencional. Não são raras as infrações administrativas que decorrem do desconhecimento das normas administrativas ou de dificuldades no cumprimento do que o ordenamento jurídico determina ao cidadão.

A legislação administrativa é esparsa e confusa, acarretando, muitas vezes, infrações decorrentes da incompreensão de tais normas jurídicas. Se o cidadão busca o Poder Público com o desígnio de obter informações para o devido cumprimento de seus deveres, compete à autoridade pública dar informações corretas e adequadas no intuito de evitar infrações desnecessárias. Ao aplicar eventuais sanções em virtude de suas falhas de cooperação no esclarecimento dos cidadãos, a Administração Pública estará agindo de modo claramente imoral (MARRARA, 2016).

Dessa forma, à Administração Pública, na esfera do processo administrativo cooperativo, são conferidos os deveres de esclarecimento, de prevenção, de consulta ou diálogo e de auxílio. São esses deveres que direcionam o comportamento da autoridade administrativa, encontrando-se disseminados em vários princípios norteadores do Processo Administrativo Disciplinar e da própria Administração Pública.

Poder-se-ia supor que a consagração de um sistema processual cooperativo, pautado pelo generoso diálogo entre os interessados e a autoridade administrativa, divergiria da ideia de razoável duração do processo administrativo, posto que a observação dos deveres de esclarecimento, consulta e prevenção acarretaria a abertura de mais prazos e maior precisão na fundamentação das decisões.

Relevante observar, todavia, que o tempo empregado para o atendimento daqueles deveres, a médio e longo prazo, pode se configurar compensador, pois o progresso na comunicação estabelecida entre o administrado e a autoridade administrativa, adequa-se a noção constitucional de um contraditório substancial, conduzindo à prolação de decisões qualitativamente melhores e mais bem fundamentadas, as quais certamente poderão evitar uma futura alteração no âmbito do Poder Judiciário.

A cooperação aqui tratada não resulta no dever do servidor público ajudar a Administração Pública a ter êxito no processo e, consequentemente, trabalhar contra si próprio. Ao revés disso, o que se pretende é que o servidor público e a Administração mutuamente cooperem para que o processo administrativo disciplinar tenha o melhor 
rendimento possível, agindo de forma proba, leal e efetivamente comprometida com a rápida solução da lide.

Sendo o Direito Administrativo um ramo do Direito Público, o exercício da função administrativa pelo Estado é um dever e não discricionariedade, ou seja, a Administração Pública tem o dever de agir, atuando na defesa do interesse público.

Deste modo, quando o Estado atua, legitimamente no cumprimento da função estatal, estabelecendo restrições ao agente administrativo, por meio do processo administrativo disciplinar, a autoridade administrativa tem o dever de seguir estritamente a cláusula do devido processo legal, nos termos da Constituição Federal de 1988, que garante aos sujeitos processuais a ampla defesa e o contraditório.

Seguindo esse entendimento, o devido processo legal administrativo é justamente o processo administrativo alinhado à ideia do princípio da cooperação, em razão do processo cooperativo adotar uma via procedimental participativa e dialética para se chegar a produção de uma decisão justa e efetiva, num contexto do Estado Democrático de Direito, tutelando os preceitos ligados à dignidade da pessoa humana na medida em que reduz arbitrariedades e abuso de poder por parte da Administração Pública.

\section{CONSIDERAÇÕES FINAIS}

A mudança de uma Administração Pública centralizada e unilateral para um modelo dialógico é compatível com a pluralidade de interesses públicos nas sociedades globalizadas e com a necessidade de maior eficiência na gestão pública, adequando a disciplina administrativa ao Estado Democrático de Direito e aos pilares de uma Constituição Cidadã.

A decisão proferida pela autoridade administrativa deve obedecer aos preceitos do debate democrático e participativo dos litigantes. É de suma importância o papel ativo e cooperativo das partes no decurso do processo, objetivando a obtenção da decisão de mérito efetiva, legítima e em tempo razoável.

Assim, a autoridade administrativa deve buscar uma maior participação dos envolvidos no processo administrativo, através de um amplo diálogo sobre as questões controversas, o que irá legitimar a decisão proferida, já que as partes participarão cooperativamente para se chegar a mesma, bem como propiciará a aceitação da decisão de uma forma menos impositiva e evitando surpresas. 
No âmbito do processo administrativo disciplinar, portanto, deve-se reconhecer ao interessado sua efetiva contribuição na formação da decisão administrativa não apenas trazendo subsídios fáticos e jurídicos para o livre convencimento da autoridade, mas participando da construção do processo de tomada de decisão, cooperando, portanto, com maior grau de racionalidade, legitimidade e eficiência da mesma.

A cooperação no PAD é entendida como o dever do servidor público e da Administração mutuamente cooperem para que o processo administrativo disciplinar tenha o melhor rendimento possível, ambos agindo de forma proba, leal e efetivamente comprometida com a rápida solução da lide.

Destarte, no que tange ao cumprimento da função pública, o processo cooperativo, que possui a boa-fé, o devido processo legal e o contraditório como fundamentos constitucionais basilares, é adequadamente aplicável ao Processo Administrativo Disciplinar.

Com a cooperação processual trazida pelo novo Código de Processo Civil, busca-se o equilíbrio entre as partes processuais na construção conjunta da decisão e não somente havendo a sua imposição, sendo dever da Administração Pública impulsionar o processo administrativo de forma a não dificultar a construção de um ambiente cooperativo, mas sim permitindo a discussão, maturação e construção de uma decisão que se adequa a uma jurisdição administrativa democrática, superando a função dos interessados de meros coadjuvantes na construção da decisão pública.

\section{REFERÊNCIAS}

ALEXY, Robert. Teoria dos direitos fundamentais. Trad. Virgílio Afonso da Silva. 2. ed. São Paulo: Malheiros, 2011.

ÁVILA, Humberto. Repensando o "princípio da supremacia do interesse público sobre o particular". In: SARMENTO, Daniel (org.). Interesses públicos versus interesses privados: desconstruindo o princípio da supremacia do interesse público. Rio de Janeiro: Lumen Juris, 2007.

BARREIROS, Lorena Miranda Santos. Fundamentos constitucionais do princípio da cooperação processual. Salvador: Jus Podivm, 2013.

BASTOS, Celso Ribeiro; MARTINS, Ives. Comentários à Constituição do Brasil. 3. ed. Saraiva: São Paulo, 2004.

BINENBOJM, Gustavo. Uma teoria do direito administrativo. Direitos Fundamentais, Democracia e Constitucionalização. $2^{\mathrm{a}}$ ed. Rio de Janeiro: Renovar, 2008. 
BONAVIDES, Paulo. Curso de direito constitucional. 13ª ed. São Paulo: Malheiros, 2003.

CANOTILHO, José Joaquim Gomes. Direito constitucional e teoria da constituição. Coimbra: 1999.

CUNHA, Leonardo Carneiro da. O Princípio contraditório e a cooperação no processo, 2013. Disponível em <http://www.leonardocarneirodacunha.com.br/artigos/o-principiocontraditorio-e-a-cooperacao-no-processo/> . Acesso em 04 de setembro de 2018.

DIDIER JÚNIOR, Fredie. Curso de direito processual civil: introdução ao direito processual civil, parte geral e processo de conhecimento. 19. ed. Salvador: Juspodivm, 2017.

FERRAZ, Sérgio; DALlarI, Adilson Abreu. Processo Administrativo. 2 ed., São Paulo: Malheiros, 2007.

FRANÇA, Vladimir da Rocha. Contraditório e invalidação administrativa no âmbito da Administração Pública federal. In: FIGUEIREDO, Lúcia Valle (Coord.). Devido processo legal na administração pública. São Paulo: Max Limonad, 2001.

GRINOVER, Ada Pelegrini. Diligência e inspeção no processo administrativo: observações sobre o devido processo legal. Revista de Direito Privado. São Paulo: Revista dos Tribunais, n. 43 , v. 11, 2010.

GOUVEIA, Lúcio Grassi de. O dever de cooperação dos juízes e tribunais com as partes: uma análise sob a ótica do Direito Comparado. Revista da ESMAPE, Recife. v.5, nº 11, jan/jun 2000.

HENRIQUES, Antonio; MEDEIROS, João Bosco. Metodologia científica na pesquisa jurídica. 9. ed., rev. e reform. São Paulo: Atlas, 2017.

MARINONI, Luiz Guilherme; ARENHART, Sérgio Cruz; MITIDIERO, Daniel. Novo código de processo civil comentado. São Paulo: Revista dos Tribunais, 2015.

MARINONI, Luiz Guilherme. Novo Curso de Processo Civil [livro eletrônico]: teoria do processo civil. v. 1. São Paulo: Revista dos Tribunais, 2016.

MARRARA, Thiago. O conteúdo do princípio da moralidade: probidade, razoabilidade e cooperação. Revista Digital de Direito Administrativo. vol. 3, n. 1, 2016. Disponível em: <http://www.periodicos.usp.br/rdda/article/viewFile/108986/107560>. Acesso em: 04 de setembro de 2018.

MEDAUAR, Odete. A processualidade no direito administrativo. $2^{\mathrm{a}}$ ed. São Paulo: Revista dos Tribunais, 2008.

MEDAUAR, Odete. O direito administrativo em evolução. $2^{\mathrm{a}}$. ed. São Paulo: Revista dos Tribunais, 2003.

MEDINA, José Miguel Garcia. Novo Código de Processo Civil Comentado. São Paulo: Revista dos Tribunais, 2015. 
MELLO, Celso Antônio Bandeira de. Curso de Direito Administrativo. $31^{\text {a }}$ Ed. São Paulo: Malheiros, 2014.

MITIDIERO, Daniel. Colaboração no processo civil: pressupostos sociais, lógicos e éticos. 2. ed. São Paulo: Revista dos Tribunais, 2011. v.14.

MOREIRA, Egon Bockmann. O novo Código de Processo Civil e sua aplicação no processo administrativo. Revista de Direito Administrativo, Rio de Janeiro, v. 273, p. 313-334, set./dez. 2016. Disponível em:

<http://bibliotecadigital.fgv.br/ojs/index.php/rda/article/view/66665/64689>. Acesso em: 04 de setembro de 2018.

MOREIRA, Egon Bockmann. Processo administrativo: princípios constitucionais e a Lei 9.784/99. 4 ed., atual, rev. e aum. São Paulo: Malheiros, 2010.

MOREIRA NETO, Diogo de Figueiredo. Poder, direito e estado. O direito administrativo em tempos de globalização. Belo Horizonte: Fórum, 2011.

NUNES, Dierle José Coelho. Processo jurisdicional democrático. Curitiba: Juruá, 2008.

OLIVEIRA, Carlos Alberto Álvaro de. Do formalismo no processo civil: proposta de um formalismo-valorativo. 4. ed. São Paulo: Saraiva, 2010.

SARLET, Ingo Wolfgang, MARINONI, Luiz Guilherme, MITIDIERO, Daniel. Curso de direito constitucional. São Paulo: Editora Revista dos Tribunais, 2012.

SIQUEIRA, Mariana de. Interesse público no direito administrativo brasileiro: da construção da moldura à composição da pintura. Rio de Janeiro: Lumen Juris, 2016.

SILVA, José Afonso da. Curso de direito constitucional positivo. $31^{\mathrm{a}}$ ed. São Paulo: Malheiros, 2008.

STRECK, Lênio Luiz; DELFINO, Lúcio; BARBA, Rafael Giorgio Dalla; LOPES, Ziel Ferreira. APOSTA NA BONDADE: A cooperação processual do novo CPC é

incompatível com a Constituição. Disponível em: <https://www.conjur.com.br/2014-dez23/cooperacao-processual-cpc-incompativel-constituicao>. Acesso em: 04 de setembro de 2018.

SUNDFELD, Carlos Ari. A importância do procedimento administrativo. Revista de Direito Público, n. 84, out./dez. 1987. 
THEODORO JÚNIOR, Humberto. Curso de Direito Processual Civil: Teoria geral do direito processual civil, processo de conhecimento e procedimento comum. 56. ed. rev., atual. e ampl. v.1. Rio de Janeiro: Forense, 2015.

THEODORO JÚNIOR, Humberto; NUNES, Dierle José Coelho; BAHIA, Alexandre de Melo Franco; PEDRON, Flávio Quinaud. Novo Código de Processo Civil: Fundamentos e Sistematização. São Paulo: Forense, 2015.

\title{
THE PRINCIPLE OF COOPERATION IN THE FRAMEWORK OF THE DISCIPLINARY ADMINISTRATIVE PROCESS
}

\begin{abstract}
This article investigates the possibility or otherwise of applying the principle of cooperation, also called the principle of collaboration, in the administrative disciplinary process. For this, the importance of the administrative process in the context of contemporary Public Administration is addressed. It also analyzes the spirit of the New Code of Civil Procedure and conceptualizes one of its basic foundations, the cooperation. Subsequent and subsidiary applicability of this Code is verified to all administrative processes governed by other laws, including within the administrative disciplinary process. Finally, the principle of due process and the principle of procedural cooperation in the administrative procedure, determining their effects and duties, is delimited. In order to carry out this study, a bibliographic review of national and foreign works related to the subject was carried out, using the method of inductive approach, based on the constitutional and procedural bases of the Brazilian legal system.
\end{abstract}

Keywords: Administrative process. New code of civil procedure. Principle of cooperation. 